\title{
MORPHOLOGICAL AND BIOCHEMICAL CONSTITUENTS INFLUENCING APHIDS AND WHITEFLIES TOLERANCE IN TOMATO GENOTYPES
}

\author{
BC ANU, T SAHA*, S AKhtAR ${ }^{1}$ AND K Kumari \\ Department of Entomology, Bihar Agricultural University, Sabour 813210, \\ Bhagalpur, Bihar, India
}

Keywords: Tomato genotypes, Sucking pests, Morphological and biochemical traits, Tolerance

\begin{abstract}
Effects of morphological and biochemical constituents on the population of sucking insect pests infesting tomato plant were evaluated. Among the twenty genotypes evaluated under field condition at different seasons (summer, kharif, rabi), it revealed that the genotypes namely BRDT-1, EC 620421, Solanum peruvianum, EC 538455 and S. cheesmaniae had minimum number of aphid and whitefly population throughout all the three seasons due to their morphological traits like more trichome density and thick stem diameter as well as the presence of biochemical attributes like phenol and tannins which were present in those genotypes at higher concentration. The higher content of leaf chlorophyll had resistance effect against the population of aphid and whitefly, while total sugar content did not have any significant effect on resistance.
\end{abstract}

\section{Introduction}

Tomato (Solanum lycopersicon L.) is one of the major and remunerative vegetable crops which provide an excellent amount of vitamin $\mathrm{C}$ and $\mathrm{E}$. India ranks second in tomato production after China (FAO 2017). Tomato is attacked by large number of insect pests including sucking pests like Whitefly (Bemisia tabaci Genn.) and Aphid (Aphis gossypii Glov.) from emergence in the seed bed until its harvest. Whitefly alone can cause $10-90 \%$ damage depending upon the severity of the infestation and crop stage (Setiawati et al. 2009).

Plant metabolites play a major role in the adaptation of plants to the changing environment and in overcoming stress constraints. Earlier reports suggested that the phenols have been documented to serve as defense compound through various means such as repelling the feeding by B. tabaci (Hagg et al. 2013). The biochemical component of leaf like total phenol exhibits a negative correlation with the sap sucking insects' infestation (Helmi and Rashwan 2015). Tannins are also considered to be the most important secondary plant compounds involved in plant defense against insects and diseases (Swain et al. 1979). Leaf damage by whitefly have significant and negative correlation with the tannin content (Mwila et al. 2017). The most prominent tomato plant morphplogical characters that contribute to whitefly antibiosis are glandular trichomes (Muigai et al. 2002). Trichome density have negative correlation with the eggs, nymphs and adults of whitefly and that of aphid population (Taggar and Gill 2012, Amin et al. 2017). The identification of morphological and biochemical characteristics from insect resistant genotypes is of most practical significance. Considering the previous research findings the present investigation was undertaken to assess the morphological and biochemical traits of tomato genotypes for their relative resistance against sucking insect pests.

*Author for correspondence: <tamoghnasaha1984@gmail.com>. ${ }^{1}$ Department of Horticulture (Vegetable and Floriculture), Bihar Agricultural University, Sabour 813210, Bhagalpur, Bihar, India. 


\section{Materials and Methods}

The present experiment was conducted at Vegetable Research Plot, Bihar Agricultural College, Sabour during three seasons (summer, kharif and rabi 2018) under in field condition and biochemical studies was conducted in Laboratory of Horticulture, of the same college. A total of 20 genotypes of tomato were collected from various parts of India (Table 1). These were screened for their relative resistance against aphid and whitefly. The trial was laid out in Randomized Block Design (RBD) having plot size $2 \mathrm{~m} \times 2 \mathrm{~m}$ with spacing of $50 \mathrm{~cm} \times 50 \mathrm{~cm}$ and replicated thrice. The populations of whiteflies and aphids were recorded by counting the number of adults from top, middle and bottom leaves of each of ten randomly selected plants per plot during early morning hours at weekly intervals.

Morphological characteristics like stem diameter $(\mathrm{mm})$ and trichome density (number per $\mathrm{cm}^{2}$ ) were recorded according to the method outlined by Wagh et al. (2012) from five randomly selected plants in each replication. Total leaf chlorophyll $(\mathrm{mg} / \mathrm{g})$ was calculated following the method outlined by Arnon (1949).

Biochemical traits like total phenol content (mg CE/100 $\mathrm{g}$ fw) was estimated spectrophotometrically using Folin-Ciocalteau reagent (FCR) (Singleton et al. 1999), total sugar content was determined by Fehling's method (Sadasivam and Manickam 1992) and tannin was estimated by Folin-Denis method (Ram and Mehrotra 1993). The experiment was laid out in Randomized Block Design. The values of critical difference (CD) were analyzed at 5\% level of significance.The analysis of variance (ANOVA) was set as explained by Gomez and Gomez (1983). After an ANOVA, mean separation was done following Duncan multiple range tests for comparison test.

\section{Results and Discussion}

There was a difference in the number of aphid and whitefly population among the different genotypes tested under field condition. It revealed that the mean number of aphids in Solanum peruvianum ( 0.59 per leaf) and EC 620421 ( 0.60 per leaf) showed least aphid population as compared to other genotypes, whereas, mean maximum number of aphid population was recorded with VRT-101A (0.79 per leaf) and Sun Cherry (0.78 leaf) (Table 1). In case of mean whitefly population, the minimum population was noticed in the genotypes EC 620421 ( 0.51 per leaf) and Solanum peruvianum ( 0.58 per leaf), whereas maximum population was observed in BRDT-3 (0.82 per leaf) and CLN 1621L (0.78 per leaf) (Table 1$)$.

The maximum stem diameter was observed in the genotypes BRDT 3 and Arka Vikas whilst minimum stem diameter was noticed in WIR 3956 (Table 2). However, correlation study revealed that stem diameter had significant and positive correlation with both aphid and whitefly $(\mathrm{r}=$ $* * 0.368$ and $* * 0.267$ ) population (Table 3 ). The present findings are in conformity with the results reported by Rohilla et al. (1990) who found that the thickness of stem between the epidermis and phloem was positively correlated with resistance to mustard aphids.

The trichome density at upper surface indicated that there was a wide range of variation (Table 2). The maximum trichome density on upper surface was recorded in IIHR 2486 and Solanum pimpinellifolium while, the genotypes WIR 13708 and Sun Cherry had minimum trichome density than other genotypes. However, maximum trichome density at lower surface was recorded with the genotypes BRDT 3 and IIHR 2486 whilst the genotypes, WIR 13708 had minimum trichome density as compared to other genotypes (Table 2). Correlation study depicted that trichome density at upper and lower surface had non-significant positive correlation with aphid population $\left(\mathrm{r}=0.042^{\mathrm{NS}}\right.$ and $\left.0.210^{\mathrm{NS}}\right)$, whereas, in whitefly, it showed non-significant negative correlation $\left(\mathrm{r}=-0.245^{\mathrm{NS}}\right.$ and $\left.-0.245^{\mathrm{NS}}\right)$ (Table 3$)$. The present findings are in agreement 
with those of Leite et al. (2006), who reported that the non-glandular or low density trichomes were not important for reducing aphid population. Taggar and Gill (2012) found negative correlation of trichome density with the eggs, nymphs and adults of whitefly. Bindu and Pramanik (2017) found trichome density was negatively correlated with the population of whitefly.

Table 1. Population of aphid and whitefly against different tomato genotypes.

\begin{tabular}{lcc}
\hline Genotype & $\begin{array}{c}\text { Mean aphid population } \\
\text { (per 3 leaves per plant) }\end{array}$ & $\begin{array}{c}\text { Mean whitefly population } \\
\text { (per 3 leaves per plant) }\end{array}$ \\
\hline Arka Vikas & $0.74^{\text {abcd }}$ & $0.70^{\text {cdefgh }}$ \\
Sel 18 & $0.74^{\text {abcd }}$ & $0.64^{\text {hi }}$ \\
Superbug SPS & $0.77^{\text {abc }}$ & $0.71^{\text {cdef }}$ \\
VRT-101A & $0.79^{\mathrm{a}}$ & $0.70^{\text {cdefg }}$ \\
WIR 13708 & $0.73^{\text {cd }}$ & $0.74^{\text {bcd }}$ \\
WIR 3956 & $0.76^{\text {abc }}$ & $0.64^{\text {ghi }}$ \\
Sun Cherry & $0.78^{\text {ab }}$ & $0.73^{\text {bcd }}$ \\
Arka Meghali & $0.73^{\text {bcd }}$ & $0.76^{\text {bc }}$ \\
EC 538380 & $0.75^{\text {abcd }}$ & $0.75^{\mathrm{bc}}$ \\
IIHR 2486 & $0.74^{\text {abcd }}$ & $0.73^{\text {bcd }}$ \\
EC 620421 & $0.60^{\mathrm{f}}$ & $0.51^{\mathrm{k}}$ \\
BRDT-1 & $0.60^{\mathrm{f}}$ & $0.62^{\mathrm{ij}}$ \\
CLN 1621L & $0.75^{\mathrm{abc}}$ & $0.78^{\mathrm{ab}}$ \\
Pusa Rohini & $0.70^{\mathrm{de}}$ & $0.73^{\mathrm{bcde}}$ \\
Solanum peruvianum & $0.59^{\mathrm{f}}$ & $0.58^{\mathrm{j}}$ \\
S. chilenseyellow & $0.73^{\mathrm{bcd}}$ & $0.74^{\mathrm{bc}}$ \\
S. cheesmaniae & $0.67^{\mathrm{e}}$ & $0.65^{\mathrm{fghi}}$ \\
S. pimpinellifolium & $0.77^{\mathrm{abc}}$ & $0.68^{\mathrm{defghi}}$ \\
EC 538455 & $0.65^{\mathrm{e}}$ & $0.67^{\mathrm{efghi}}$ \\
BRDT 3 & $0.78^{\mathrm{ab}}$ & $0.82^{\mathrm{a}}$ \\
SEm \pm & 0.01 & 0.01 \\
CD (p=0.05) & 0.03 & 0.04 \\
CV (\%) & 3.11 & 3.74 \\
\hline
\end{tabular}

Means in a column sharing same letter are not significantly different by DMR Test at $\mathrm{p}<0.05$.

Leaf chlorophyll was found to be highest in EC 620421 and BRDT-1, while Arka Meghali and CLN 1621L had the least content of leaf chlorophyll (Table 2). The correlation study showed that both aphid and whitefly population had significant negative correlation with total chlorophyll content $\left(\mathrm{r}=-0.553^{* *},-0.569^{* *}\right)$ (Table 3 ). The present findings are more or less similar to the earlier findings of Helmi and Rashwann (2015), who reported that Photosynthetic pigments (chlorophyll a, chlorophyll $\mathrm{b}$ and carotenoids) showed negative relationship with sap sucking insects. 
Table 2. Morphological traits of different tomato genotypes for their relative resistance against sucking insect pests.

\begin{tabular}{|c|c|c|c|c|}
\hline \multirow[t]{2}{*}{ Genotype } & \multirow{2}{*}{$\begin{array}{l}\text { Stem diameter } \\
(\mathrm{mm}) \\
\text { Mean } \pm \text { S.E }\end{array}$} & \multicolumn{2}{|c|}{$\begin{array}{l}\text { Trichome density } \\
\left(\text { number per } \mathrm{cm}^{2}\right)\end{array}$} & \multirow{2}{*}{$\begin{array}{l}\text { Total leaf } \\
\text { chlorophyll } \\
(\mathrm{mg} / \mathrm{g}) \\
\text { Mean } \pm \text { S.E }\end{array}$} \\
\hline & & $\begin{array}{c}\text { Upper surface } \\
\text { Mean } \pm \text { S.E }\end{array}$ & $\begin{array}{c}\text { Lower surface } \\
\text { Mean } \pm \text { S.E }\end{array}$ & \\
\hline Arka Vikas & $1.71 \pm 0.03^{\mathrm{a}}$ & $111.33 \pm 4.67^{\mathrm{f}}$ & $136.67 \pm 5.77^{\mathrm{i}}$ & $4.22 \pm 0.12^{\mathrm{e}}$ \\
\hline Sel. 18 & $1.39 \pm 0.03^{\text {cdef }}$ & $71.56 \pm 2.70^{\mathrm{g}}$ & $88.22 \pm 4.08^{\mathrm{jk}}$ & $2.52 \pm 0.13^{\mathrm{gh}}$ \\
\hline Superbug SPS & $1.51 \pm 0.02^{\mathrm{bcd}}$ & $64.56 \pm 2.50^{\mathrm{g}}$ & $80.44 \pm 1.94^{\mathrm{k}}$ & $3.57 \pm 0.10^{f}$ \\
\hline VRT-101A & $1.68 \pm 0.04^{\mathrm{a}}$ & $66.44 \pm 1.35^{\mathrm{g}}$ & $88.11 \pm 5.25^{\mathrm{jk}}$ & $4.29 \pm 0.04^{\mathrm{e}}$ \\
\hline WIR 13708 & $1.49 \pm 0.07^{\mathrm{cd}}$ & $62.78 \pm 1.64^{\mathrm{g}}$ & $74.44 \pm 0.95^{\mathrm{k}}$ & $2.69 \pm 0.04^{\mathrm{g}}$ \\
\hline WIR 3956 & $1.26 \pm 0.01^{\mathrm{f}}$ & $97.78 \pm 1.35^{\mathrm{f}}$ & $112.78 \pm 2.44^{\mathrm{ij}}$ & $4.38 \pm 0.08^{\mathrm{e}}$ \\
\hline Sun Cherry & $1.41 \pm 0.04^{\text {cde }}$ & $63.22 \pm 5.99^{\mathrm{g}}$ & $78.78 \pm 5.24^{\mathrm{k}}$ & $2.10 \pm 0.09^{\mathrm{h}}$ \\
\hline Arka Meghali & $1.71 \pm 0.03^{\mathrm{a}}$ & $168.89 \pm 8.17^{\mathrm{cd}}$ & $262.89 \pm 18.85^{\mathrm{cde}}$ & $0.87 \pm 0.13^{\mathrm{i}}$ \\
\hline EC 538380 & $1.37 \pm 0.07^{\mathrm{def}}$ & $155.89 \pm 3.60^{\mathrm{de}}$ & $276.33 \pm 9.51^{\mathrm{bcd}}$ & $3.91 \pm 0.13^{\text {ef }}$ \\
\hline IIHR 2486 & $1.33 \pm 0.04^{\mathrm{ef}}$ & $204.00 \pm 6.45^{\mathrm{a}}$ & $295.67 \pm 7.73^{b}$ & $5.23 \pm 0.05^{\mathrm{cd}}$ \\
\hline EC 620421 & $1.46 \pm 0.03^{\text {cde }}$ & $169.11 \pm 6.30^{\mathrm{cd}}$ & $233.11 \pm 20.98^{\text {efg }}$ & $6.68 \pm 0.09^{\mathrm{a}}$ \\
\hline BRDT-1 & $1.38 \pm 0.05^{\mathrm{def}}$ & $110.00 \pm 3.40^{\mathrm{f}}$ & $129.44 \pm 3.26^{\mathrm{i}}$ & $5.87 \pm 0.08^{\mathrm{b}}$ \\
\hline CLN 1621L & $1.63 \pm 0.02^{\mathrm{ab}}$ & $155.67 \pm 3.79^{\mathrm{de}}$ & $242.33 \pm 21.63^{\text {efg }}$ & $1.06 \pm 0.09^{\mathrm{i}}$ \\
\hline Pusa Rohini & $1.44 \pm 0.11^{\text {cde }}$ & $157.00 \pm 3.67^{\mathrm{de}}$ & $238.78 \pm 5.90^{\mathrm{efg}}$ & $2.73 \pm 0.06^{\mathrm{g}}$ \\
\hline Solanum peruvianum & $1.51 \pm 0.06^{\mathrm{bcd}}$ & $146.11 \pm 3.89^{\mathrm{e}}$ & $250.22 \pm 7.90^{\mathrm{def}}$ & $5.69 \pm 0.07^{b c}$ \\
\hline S. chilenseyellow & $1.43 \pm 0.02^{\text {cde }}$ & $141.33 \pm 7.23^{\mathrm{e}}$ & $193.11 \pm 6.83^{\mathrm{h}}$ & $2.82 \pm 0.59^{\mathrm{g}}$ \\
\hline S. cheesmaniae & $1.42 \pm 0.04^{\text {cde }}$ & $163.89 \pm 2.35^{\mathrm{cd}}$ & $228.56 \pm 8.09^{\mathrm{fg}}$ & $5.40 \pm 0.16^{b c d}$ \\
\hline S. pimpinellifolium & $1.53 \pm 0.02^{\mathrm{bc}}$ & $187.44 \pm 3.19^{\mathrm{b}}$ & $280.78 \pm 10.52^{\mathrm{bc}}$ & $2.73 \pm 0.11^{\mathrm{g}}$ \\
\hline EC 538455 & $1.40 \pm 0.03^{\text {cde }}$ & $166.11 \pm 11.08^{\mathrm{cd}}$ & $218.44 \pm 4.15^{\mathrm{gh}}$ & $5.67 \pm 0.19^{b c}$ \\
\hline BRDT 3 & $1.77 \pm 0.04^{\mathrm{a}}$ & $176.67 \pm 5.20^{\mathrm{bc}}$ & $371.00 \pm 5.77^{\mathrm{a}}$ & $5.02 \pm 0.19^{\mathrm{d}}$ \\
\hline $\mathrm{CD}(\mathrm{p}=0.05)$ & 0.12 & 14.27 & 25.94 & 0.49 \\
\hline $\mathrm{CV}(\%)$ & 4.83 & 6.58 & 8.07 & 7.77 \\
\hline
\end{tabular}

Means in a column sharing same letter are not significantly different by DMR Test at $\mathrm{p}<0.05$.

Table 3. Correlation between morphological traits of tomato genotypes and sucking insect pests.

\begin{tabular}{lcc}
\hline Morphological traits & Aphid & Whitefly \\
\hline $\begin{array}{l}\text { Stem diameter }(\mathrm{mm}) \\
\text { Trichome density } \\
\left(\text { number per } \mathrm{cm}^{2}\right) \text { Upper surface }\end{array}$ & $0.368^{* *}$ & $0.267^{*}$ \\
$\begin{array}{l}\text { Trichome density } \\
\left(\text { number per } \mathrm{cm}^{2}\right) \text { Lower surface }\end{array}$ & $0.042^{\mathrm{NS}}$ & $-0.245^{\mathrm{NS}}$ \\
Total leaf chlorophyll (mg/g) & $0.210^{\mathrm{NS}}$ & $-0.113^{\mathrm{NS}}$ \\
\hline
\end{tabular}

**** Indicate significance of values at $\mathrm{p}=0.01$ and 0.05 , respectively. 
Total phenol content presented in Table 4 pointed out that the genotypes Solanum peruvianum and EC 620421 had maximum amount of leaf phenol content and the genotypes WIR 13708 and EC 528380 had minimum amount of leaf phenol content. However, correlation study revealed that the total phenol content was highly significant and negatively correlated with aphid and whitefly population $\left(\mathrm{r}=-0.882^{* *},-0.748^{* *}\right)$ (Table 5). This finding is in accordance with Helmi and Rashwann (2015), who reported that the total phenol content had a negative relationship with the findings of the sucking insect infestation. Samota et al. (2018) reported that the total phenol content had a significant and negative correlation with the whitefly population. Yadav and Rana (2018) observed a negative and significant correlation between phenol content and mustard aphid infestation.

Table 4. Biochemical traits of different tomato genotypes for their relative resistance against sucking insect pests.

\begin{tabular}{|c|c|c|c|}
\hline Genotype & $\begin{array}{c}\text { Phenol content } \\
(\mathrm{mg} \mathrm{CE} / 100 \mathrm{~g} \mathrm{fw}) \\
\text { Mean } \pm \text { S.E }\end{array}$ & $\begin{array}{l}\text { Total sugar content } \\
(\%) \quad \text { Mean } \pm \text { S.E }\end{array}$ & $\begin{array}{c}\text { Tannins }(\mathrm{mg} \\
\mathrm{CE} / 100 \mathrm{~g} \mathrm{dm}) \\
\text { Mean } \pm \text { S.E }\end{array}$ \\
\hline Arka Vikas & $5.31 \pm 0.12^{\text {defgh }}$ & $4.54 \pm 1.00^{\text {bcde }}$ & $7.08 \pm 0.10^{\text {fgh }}$ \\
\hline Sel 18 & $3.14 \pm 0.26^{\mathrm{hi}}$ & $6.28 \pm 0.15^{\mathrm{ab}}$ & $6.66 \pm 0.26^{\mathrm{h}}$ \\
\hline Superbug SPS & $3.26 \pm 0.53^{\text {ghi }}$ & $6.73 \pm 1.17^{\mathrm{a}}$ & $7.63 \pm 0.13^{\text {cde }}$ \\
\hline VRT-101A & $6.19 \pm 0.22^{\mathrm{de}}$ & $6.56 \pm 0.52^{\mathrm{a}}$ & $7.46 \pm 0.07^{\mathrm{def}}$ \\
\hline WIR 13708 & $2.41 \pm 0.14^{\mathrm{i}}$ & $3.04 \pm 0.15^{\mathrm{de}}$ & $7.67 \pm 0.09^{\text {cde }}$ \\
\hline WIR 3956 & $5.38 \pm 0.16^{\text {defgh }}$ & $6.62 \pm 0.58^{\mathrm{a}}$ & $7.15 \pm 0.14^{\mathrm{fg}}$ \\
\hline Sun Cherry & $4.36 \pm 0.93^{\text {efghi }}$ & $3.18 \pm 0.08^{\mathrm{de}}$ & $7.40 \pm 0.05^{\mathrm{ef}}$ \\
\hline Arka Meghali & $3.66 \pm 0.13^{\text {efghi }}$ & $5.73 \pm 0.60^{\mathrm{ab}}$ & $6.16 \pm 0.08^{\mathrm{i}}$ \\
\hline EC 538380 & $2.67 \pm 0.10^{\mathrm{i}}$ & $3.00 \pm 0.21^{\mathrm{e}}$ & $6.72 \pm 0.10^{\mathrm{gh}}$ \\
\hline IIHR 2486 & $6.01 \pm 0.17^{\mathrm{de}}$ & $4.66 \pm 1.13^{\text {bcde }}$ & $7.64 \pm 0.06^{\text {cde }}$ \\
\hline EC 620421 & $21.33 \pm 0.21^{\mathrm{a}}$ & $2.94 \pm 0.07^{\mathrm{e}}$ & $8.33 \pm 0.08^{\mathrm{ab}}$ \\
\hline BRDT-1 & $13.54 \pm 1.97^{\mathrm{c}}$ & $5.72 \pm 0.10^{\mathrm{ab}}$ & $7.94 \pm 0.10^{\mathrm{bc}}$ \\
\hline CLN 1621L & $7.17 \pm 0.18^{d}$ & $5.27 \pm 0.40^{\mathrm{abc}}$ & $6.82 \pm 0.09^{\mathrm{gh}}$ \\
\hline Pusa Rohini & $5.86 \pm 0.20^{\mathrm{def}}$ & $5.34 \pm 0.59^{\mathrm{abc}}$ & $7.10 \pm 0.43^{\mathrm{fgh}}$ \\
\hline Solanum peruvianum & $22.87 \pm 0.67^{\mathrm{a}}$ & $4.89 \pm 0.07^{\mathrm{abcd}}$ & $7.67 \pm 0.08^{\text {cde }}$ \\
\hline S. chilenseyellow & $3.38 \pm 0.60^{\mathrm{fghi}}$ & $6.27 \pm 0.87^{\mathrm{ab}}$ & $7.62 \pm 0.06^{\text {cde }}$ \\
\hline S. cheesmaniae & $14.36 \pm 2.25^{\mathrm{c}}$ & $4.56 \pm 0.14^{\text {bcde }}$ & $7.88 \pm 0.04^{\mathrm{cd}}$ \\
\hline S. pimpinellifolium & $4.48 \pm 0.24^{\text {efghi }}$ & $3.55 \pm 0.50^{\text {cde }}$ & $7.46 \pm 0.13^{\mathrm{def}}$ \\
\hline EC 538455 & $18.92 \pm 0.59^{b}$ & $3.52 \pm 0.13^{\text {cde }}$ & $8.69 \pm 0.09^{a}$ \\
\hline BRDT 3 & $5.71 \pm 0.28^{\operatorname{defg}}$ & $3.19 \pm 0.07^{\mathrm{de}}$ & $7.53 \pm 0.10^{\text {cde }}$ \\
\hline $\mathrm{CD}(\mathrm{p}=0.05)$ & 2.19 & 1.45 & 0.40 \\
\hline $\mathrm{CV}(\%)$ & 16.66 & 18.48 & 3.26 \\
\hline
\end{tabular}

Means in a column sharing same letter are not significantly different by DMR Test at $\mathrm{p}<0.05$. 
Superbug SPS and WIR 3956 were the genotypes that contained highest amount of total sugar. However, the genotypes namely EC 620421 and EC 528380 had lesser total sugar content in fruit (Table 4). Correlation study showed that the total sugar content had non-significant positive correlation with aphid population $\left(\mathrm{r}=0.169^{\mathrm{NS}}\right)$, whereas, in whitefly, it showed nonsignificant negative correlation $\left(\mathrm{r}=-0.033^{\mathrm{NS}}\right)$ (Table 5). The present findings are in accordance with the earlier findings of Srujana (2014), who reported that total sugars at reproductive stage had no significant influence on incidence of sucking insect pests in selected urdbean genotypes.

Table 5. Correlation between biochemical traits of tomato genotypes and sucking insect pests.

\begin{tabular}{lcc}
\hline Biochemical traits & Aphid & Whitefly \\
\hline Total phenol content & $-0.882^{* *}$ & $-0.748^{* *}$ \\
Total sugar & $0.169^{\mathrm{NS}}$ & $-0.033^{\mathrm{NS}}$ \\
Tannin content & $-0.544^{* *}$ & $-0.480^{* *}$ \\
\hline
\end{tabular}

$*, * *$ Indicate significance of values at $\mathrm{p}=0.01$ and 0.05 , respectively.

Leaf tannin was observed to be the highest in EC 538455 and EC 620421 whereas, Arka Meghali and Sel 18 conatined the least (Table 4). Correlation study revealed that the tannin content exhibited significant negative correlation with both aphid and whitefly population whitefly $\left(\mathrm{r}=-0.544^{* *},-0.480^{* *}\right)$ (Table 5). The present results are in agreement with the earlier results of Mwila et al. (2017), who reported that the tannin activity was significantly $(\mathrm{p}<0.05)$ negatively correlated with leaf damage $(\mathrm{r}=-0.569)$, nymph count $(\mathrm{r}=-0.774)$ and with whitefly count $(\mathrm{r}=$ -0.442). Zhang et al. (2003) found that the aphid population was negatively correlated with the tannin content present in the leaf. Taggar et al. (2014) found that the tannin contents in leaves showed significant negative correlation with whitefly population (nymphs and adults). High concentration of tannins have also been reported to impart resistance to B. tabaci in cotton (Raghuraman et al. 2004).

It may be concluded that among the twenty genotypes, five genotypes namely Solanum peruvianum, EC 620421, BRDT-1, EC 538455 and S. cheesmaniae are found to be tolerant to aphid and whitefly population due to high phenol and tannin content as well as stem diameter which has significant association with aphid and whitefly population. It is evident that tolerance is conferred by combination of morphological and biochemical attributes and can be used as effective and reliable selection criteria for tolerance.

\section{Acknowledgements}

The author is thankful to the Principal, Bihar Agricultural College, Sabour for providing financial grant to carry out the research work.

\section{References}

Amin MR, Afrin R, Alam MZ, Hossain MM and Kwon YJ 2017. Effect of leaf trichomes and meteorological parameters on population dynamics of aphid and Jassid in cotton. Bangladesh J. Agril. Res. 42: 13-25.

Arnon DI 1949. Spectrophotometric determination of chlorophyll. Plant Physiol. 24: 1.

Bindu SP and Pramanik A 2017. Effect of leaf characteristics on different brinjal genotypes and their correlation on insect pests infestation. Int. J. Curr. Microbiol. Appl. Sci. 6: 3752-3757.

FAO 2017. FAOSTAT. Food and Agriculture Organization of the United Nations, Rome, Italy. 
Gomez KA and Gomez RA 1983. Statistical Procedure for Agriculture Research. John Willey and Sons, New York. (2nd ed.), pp. 28-411.

Hagg JF, Zagrobelny M and Bak S 2013. Plant defense against insect herbivores. Int. J. Mol. Sci. 14: 1024297.

Helmi A and Rashwan R 2015. Susceptibility of some solanaceous plant cultivars to sap-sucking insects' infestation and their associated natural enemies. J. Plant Prot. Path. 6: 763-781.

Leite GLD, PicançoM, Zanuncio JC and Gusmao MR 2006. Factors affecting colonization and abundance of Aphis gossypii Glover (Hemiptera: Aphididae) on okra plantations. Cienc. Agrotech. 31: 337-343.

Muigai SG, Schuster DJ, Snyder JC, Scott JW, Bassett MJ and McAuslane HJ 2002. Mechanisms of resistance in Lycopersicon germplasm to the whitefly Bemisia argentifolii. Phytoparasitica 30: 347-360.

Mwila N, Rubaihayo PR, Kyamanywa S, Odong TL, Nuwamanya E, Mwala M, Agbahoungba S and Badji A 2017. Biochemical factors associated with cassava resistance to whitefly infestation. Afr. Crop Sci. J. 25: 365-385.

Raghuraman M, Gupta GP and Singh RP 2004. Biochemical constituents imparting resistance in upland cotton (Gossypium hirsutum) to whitefly (Bemisia tabaci). Indian J. Agric. Sci. 74: 505-507.

Ram PR and Mehrotra BN 1993. Compendium of Indian Medicinal Plants, (Drug Research Preparative: A CDRI Series), VOL. 2. Central Drug Research Institute, Lucknow and Publications and Information Directorate, New Delhi. pp. 453.

Rohilla HR, Ohlsson I and Kumar PR 1990. Management of mustard aphid. Proceedings of an Indo-Swedish Symposium, 4-6 September 1989, Uppsala, Sweden. pp. 92-101.

Sadasivam S and Manickam A 1992. Biochemical methods (Second edition). New Age International (P) Limited Publishers New Delhi and TNAU Coimbatore India pp. 256.

Samota RG, Jat BL and Choudhary MD 2018. Varietal screening of chilli, Capsicum annum L. against major sucking insect pests. J. Entomol. Zool. Stud. 6: 995-999.

Setiawati W, Adiarto BK and Gunaeni N 2009. Preference and infestation pattern of Bemisia tabaci (Genn) on some tomato varieties and its effect on gemini virus infestation. Indones. J. Agric. Sci. 2: 57-64.

Singleton VL, Orthofer R and Lamuela-Ranventos RM 1999. Analysis of total phenols other oxidation substrates and antioxidants by means of Folin-Ciocalteu reagent. Method Enzymol. 299: 152-178.

Swain T, Harborne JB and Van Sumere CF 1979. Phenolics in the environment. Recent Adv. Phytochem. Vol. 12. Plenum Press, New York pp. 624-637.

Srujana B 2014. Evaluation of certain genotypes against whitefly (Bemisia tabaci Gennadius) and its management on blackgram (Vigna mungo Linnaeus). M.Sc. (Agri.) Thesis, Acharya N.G. Ranga Agricultural University, Rajendranagar, Hyderabad, India.

Taggar GK and Gill RS 2012. Preference of whitefly, Bemisia tabaci, towards black gram genotypes: Role of morphological leaf characteristics. Phytoparasitica 40: 461-474.

Taggar GK, Gill RS, Gupta AK and Singh S 2014. Induced changes in the antioxidative compounds of Vigna mungo genotypes due to infestation by Bemisia tabaci (Gennadius). J. Environ. Biol. 35: 1037-1045.

Wagh SS, Pawar DB, Chandele AG and Ukey NS 2012. Biophysical mechanisms of resistance to brinjal shoot and fruit borer (Leucinodes orbonalis Guenee) in brinjal. Pest Manag. Hortic. Ecosyst. 18: 54-59.

Yadav M and Rana JS 2018. Biochemical constituent of Brassica juncea genotypes in relation to mustard aphid (Lipaphis erysimi Kalt.) infestation. J. Pharmacogn. Phytochem. 7: 938-943.

Zhang J, Xing G, Liao J, Hou Z, Wang G and Wang Y 2003. Effects of different atmospheric $\mathrm{CO}_{2}$ concentrations and soil moistures on the populations of bird cherry-oat aphid (Rhopalosiphum padi) feeding on spring wheat. Eur. J. Entomol. 100: 521-530. 